\title{
Gaining Values Education through Musical Plays
}

\author{
Prof. Dr.ÖmürBütevDolğun \\ (Department of Fine Arts Education, ArtvinCoruh University, Turkey)
}

\begin{abstract}
It could be maintained that the understanding of "learning by doing" according to John Dewey, the modern education theorist is in fact a great asset on how we reshape and reconstitute our understanding of education today. This understanding has started taking the place of traditional rote learning understanding of education as it became widespread and it was accepted. In this context; the consolidation and gaining of the values in daily life through education is also possible. Together with the connatural instincts of human; gained values subsequently are also important. Values as one of the factors that constitute social living are actually created by human in purpose of putting the social living in a certain order. An individual must abide by some social values to be accepted in society and reach the level of keeping up with social living. Alongside with the values that change according to time and environment; there also are some values that are accepted in every era and under any circumstances. While taking a look at various cultures, it is also possible to come across with different values but it can generally be observed that these values share some common directions and similarities. On grounds of educational understanding; right along with the individual's ability of selfexpression and the ability of existing in society merrily and healthily; the individual's harmony with the values in social living is also utterly important. The method of teaching children values through music that they are very keen on would be beneficial in such ways as the permanence of information learnt and the entertaining methods of multiple intelligences theory of the values that are about to be taught. In this study; original samples of the teaching values education through musical plays have being submitted.
\end{abstract}

Keywords: Value, values education, play, musical plays, learning by doing

\section{Introduction}

When it comestovalues, somebehaviouralpatternsthat define both the individual himself and the environment he lives in are thought of. Al though there are various different behavioural patterns in every society and every culture; therearealsouniversalvaluepatternsthatareaccepted in eachsociety. In the study Qualitative Research Case Studymethod is implemented.Inthisstudy 36 students in their 2nd year of Artvin Coruh UniversityD epartment of Elementary Education form the sample group. These students are divided to three groups in 12 students in eachgroup and they are asked for studying on sample events based on different values. At theend of thestudy, the groups have argued between each other and presented the samples of musical plays they thought were the best among their original studies.

\subsection{The Concept of Value}

While speaking of values, some behavioural patterns that define both the individual himself and the environment he lives in cannot be ignored.There may surely be various different behavioural patterns in every society and every culture; but it doesn't change the fact that there are also universal value patterns accepted in each society.Values aim at perfecting the individual by developing his personality in each way and bringing out the very best in him. (Aydın and Gürler, 2012:3)

As it is considered within this context;it can be said that an individual who behaves suitably to the values will be more welcomed and will be qualified as a well-adjusted person in the eyes of the society. It is known that people who do not obey the social rules are considered as "incompatible" and are being excluded from the society.Values officiate as the grips that the individuals in a society will hold on and the masts that sustain the social structure. (Özensel, 2003: 222)

\subsection{Values Education}

It can be said that the concept of values education is one of the modern education understandings that leave an extensive impression and influential concepts. Some of the purposes of education are preparing the individuals for life,making them become more conscientious, lenient and compatible; in brief contributing them to become strong by expressing themselves in more correct and easier ways in life and toning in society better as they grow older and wiser. If we are to approach it in this context; we can understand the importance of the concept of values education widely and entirely.The subjects that will be gained in values education can be found in multiple resources. In this study; the programs of The Ministry of Education for $9^{\text {th }}, 10^{\text {th }}, 11^{\text {th }}$ and $12^{\text {th }}$ grade are selected as the baseline. 
The values in this program are in the order below:

- $\quad$ Solidarity

- Leniency

- Scientificancy

- Love

- Respect

- Susceptibility

- Patriotism

- Concord

- Aesthetics

- Responsibility

- Discipline

- Self-Confidence

- Devotion

- Sharing (http://ttkb.meb.gov.tr/program2.aspx ?islem=1\&kno=88;Sayfa:21)

According to Kaya (2012), the children who are in their primary school period are between the ages of 6 and 12. The children that age are known to start developing a system of morals and values. They are also known to start having the ability of "forming groups with their coevals". (Kaya, 2012:9)

It can be said that the scientific and technological developments in our day draw the attention of the children, especially those who are in younger ages, and cause the educators search for different and more intriguing educational understandings by leaving the traditional education understandings behind. The children of our day are becoming more open-minded, more sceptical and have an ability of expressing themselves in more comfortable ways. Also the passive understanding of traditional education understanding had changed and given its place to an education understanding which is more active. Thus adjusting the concepts of learning by doing and experiencing to the education understanding has become a necessity in modern times.

\subsection{The Function of Music in Values Education}

"Music is an aesthetic expression, joyful, nonjudgmental and noncompetitive".(Kouvava,Antonopoulou,Zioga, Karali,2011: 1661) "Purposeful stimulation music education supports, strengthens and consolidates the functions of music at all levels". (Kiilu,2011: 1259) Thereby it would be beneficial in an education perspective to benefit from the emotional, behavioural features and influences of music.

With all these features, it is possible to benefit from music in almost every field. Furthermore, it looks as a rational approach to use the intriguing appeal of music especially in children's musical education. Children can express themselves easier and gain learn information they are supposed to learn and the abilities and habits they are supposed to gain especially in musical activities. It is a known fact how intensely the children gather their attention and they become all concentrated and motivated during plays. Therefore it will be nothing but beneficial to give a rather large place to musical plays in children's musical education.

"However,teaching social skills to children is much harder thanteaching academic subjects and requires specific knowledge in order to draft appropriate plans to encourage these skills, that teachers may not always have; consequently, educators may need guidance for the organization and structure of these interactive sessions".(Kouvava, Antonopoulou,Zioga, Karali, 2011:1661) Children can obtain information, develop their skills and socialise in group plays through musical plays.

According to Dilmaç (2002:12); all humanitarian values can be developed through group activities. And the musical activities that are counted as one of these activities are the most advantageous ones with the sounds and rhythms they include.

\subsection{The Concept of Play and the Musical Plays}

Music is the world of sounds which the child meets in the womb. It is the lullabies, song and folk songs he hears from the world outside after his birth. It is the nursery rhymes, counting songs and even musical plays as he plays in the streets with his coevals.Music which takes a large place in the child's life also takes place in the plays that children play. It fascinates and directly draws their attention with its world that is made of sounds. Plays, on the other hand; is signified as an activity that lets the child express himself in the most comfortable way without witnessing any obstacle or pressure. While playing a game, children isolate themselves from the environment they are in; they dive into a far different world and only concentrate on the game they are playing. For this reason it is possible for every information and ability they must learn to be gained through games. 


\section{The Purpose of The Study}

It can be said that the children are mostly only interested in themselves and think in a self-centered way, especially if they are in the $1^{\text {st }}$ grade of primary education. For this reason, the concept of music in which takes a great parts in many people's lives can indeed be benefit from.

The education of children who are little individuals is important for their developments to become the healthier and more conscientious individuals of future. The values should be gained in proper ways for the society to be knowledgeable, conscientious and healthy. In this study; original studies done by the groups that form the sample group and lead by the researcher to gain the values education by benefiting from the effective power of music will be presented.

\subsection{Method of the Study}

In the study Qualitative Research Case Study method is implemented. This method has been adapted to music education. Case Study method; is a teaching method that is based on the students' abilities of revealingsolutions and suggestions by arguing after an event or problem is being written or verbally told or a film is shown. (AydınandGürler, 2012: 126) In Case Study method the subject that will be argued can be written down as an event, told or dramatized by the students themselves as well as it can be giving by the teacher. (AydınandGürler, 2012: 126)

\subsection{The Sample Group}

36 students in their $2^{\text {nd }}$ year of ArtvinCoruh University Department of Elementary Educationvoluntarily form the sample group of this study. The students which are divided to three groups in 12 students in each group are asked to study on various sample events each based on different values. At the end of the study, the groups who haddiscussed to select their best samples among many,presented their samples of musical plays.

\subsection{The Limits of the Study}

The values "Leniency, love, respect" are given to the groups and the students had studied on these values.

\subsection{Data Collection Tools and Analysis}

At the end of the study text context have been collected and analysed. They have also analysed whether they are suitable or not in musical ways, evaluated and interpreted.

\subsection{Leniency}

\section{Findings}

It is not as hard as it seems to teach the children at early ages concepts like respecting, minding and valuing each other and each other's thoughts which are the basic elements of leniency. It is possible for children to enhance byrecognizing their behaviours and outcomes of respecting their friends who have different traits than them, knowing themselves as unique individuals, learning to cooperate with others.

A child who witnesses and learns every individual does not share the same traits but that this situation will not keep him from communicating other people; contrarily those features make them special and enrichand develop their personalities will apply to his living.This development in modern education understanding, undoubtedly, reverberated to younger individuals as well. It can also be said the individuals who are respectful and lenient to each other and each other's differences are less likely to resort to violence.It is observed that children who are actually more understanding, sensitiveto differences and far moreacquiescent than the adults are sometimes get involved to arguments andrivalries that are seenmeaningless to adults.It is possible to say these kinds of situations can be avoided by giving them values education in convenient and sufficient ways to them.The topic of teaching the concept of leniency and respecting and caring about each other, valuing each other's wills, emotions and thoughts it brings to younger individuals who are known to be more impatient and dynamic than adults and in which methods it will be taughtis a sensitive topic that is worthbeing mindfully emphasised.It may be possible to benefit from art and especially music in this respect.

Children's respect to the emotions, opinions and likings can help them thinking in a more social way by getting out of the self-centred way of thinking. It might not be hard to achieve this in case of it is implemented in a way that is convenient to children. "A main goal of leniency education, is to make our children live with and benefit from difference, create a pluralistic, fair and peaceful world society out of this difference; in other words to make creating a "peace culture" possible." (Readon, 1997:24)

Some studies can be done in classroom for children to express themselves easily and be more lenient and caring to their friends. "Counsellors and teachers in schools can help children recognize their own traits through various researches that aim to teach children avoiding expectations and clichés that can misguide them easily and show who they and the other people are." (Readon,1997:30)

The preservice teachers were given the example below to teach the value of leniency: 
"Atakan was a rather naughty boy. He used to play with his ball in the house. One day Atakan, who ignored his mother's constant warnings and keep on playing ball games inside the house, broke her mother's favourite vase. He felt very guilty and failed to glue the vase back no matter how hard he tried. He thought and thought what he was going to tell his mother and he finally decided to tell her the truth. He told his mother how sad he was to break the vase and how guilty he felt not to listen her warnings. His mother forgave him."

After the example is given, the preservice classroom teachers are asked todo an original study to teach the children the value of leniency through a musical play. The sample that is given below is chosen among all the other samples. (The movements and actions are also given beside the lyrics.)

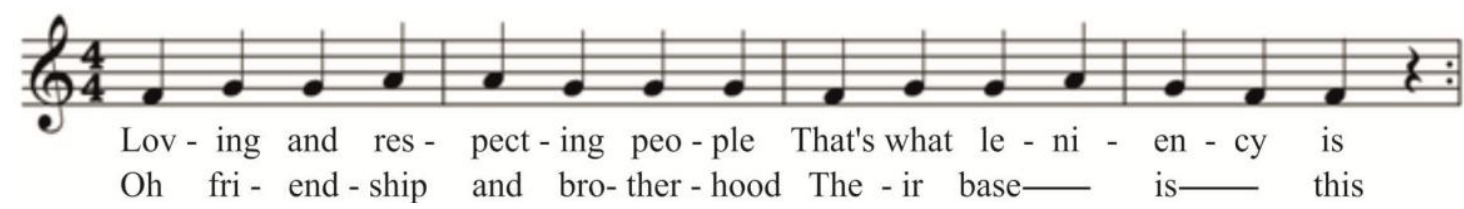

Loving and respecting people (Students hold hands)

That's what leniency is (With arms closed, they shake sideways)

Oh friendship and brotherhood (They hold hands and expand the circle)

Their base is this (They stop holding hands, put their hands on their hearts and shake sideways)

\subsection{Love}

Unconscious and intrinsic motivators are the most basic concepts in explaining human behaviours. (Kaya, 2012; 3) Accordingly, the concept of love needs to be perceived as an intrinsic motivator. Because love is a motivator that exists within since birth. While looking at the people it can be observed that some are more affectionate and loving than the others. If it is needed to be thought of in this context; the gaining of amity can be actualised byawakening and process a motivator that already exists in us since the birth.

It is a known fact children especially at young ages go through troubled times when they have siblings after a long time of being raised and treated as the only child of the family. To process the value of love, an example that can often be observed in daily life had been used.The example is as below:

"Six year old Semra had a little brother. Semra, who has been the only child or even the princess of the house up until that age and had everything she wanted in a heartbeat, was starting to feel a little lonely after her brother's birth. Yet she had never been left alone for that there has always been somebody to take care of her. And now her mother, father and every other person around her was only taking care of her little brother.Semra had almost become invisible and she was deeply hurt for this reason. Her answer was already thought of when her mother has seen her crying: "Everybody is only interested in brother and never in me." Her mother told her how terribly she was wrong and how they love Semra dearly. When her mother noticed that Semra was not so convinced, she took Semra to her brother's crib and told her how young her brother was to feed himself, change his diapers and go anywhere and or even keep on living if they do not take care of him. Semra listened as her mother gives the examples and though her mother was right. From that day she loved her brother even more and started to protect him."

The musical play sample that is based on this example is given below:

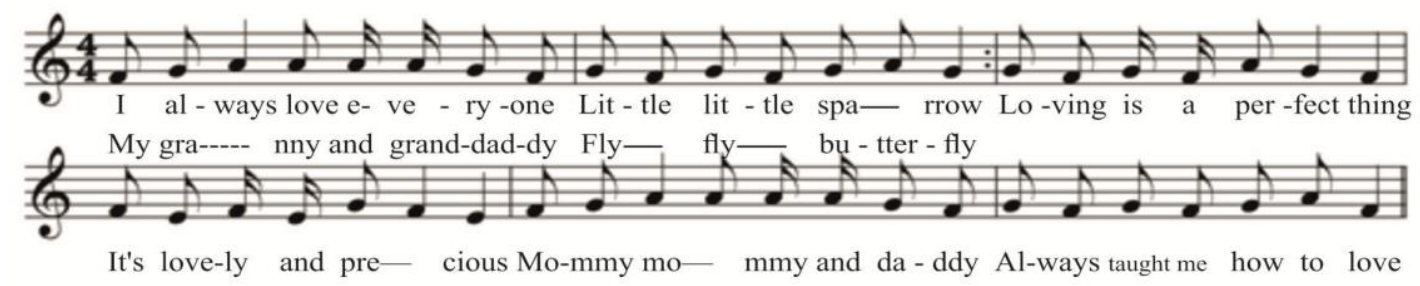

I always love everyone (Students shape a circle with their arms)

Little little sparrow (They flap their arms and imitate flying)

My granny and granddaddy (One group stroke their cheeks, another group walk with canes)

Fly fly butterfly (Each group dance and turn around in a circle while imidating flying moves)

Loving is a perfect thing (Students all put their hands on their hearts)

It's lovely and precious (They spread their arms first to the right thlen to the left)

Mommy mommy and daddy (They clap their hands)

Always taught me how to love(Students all make a heart symbol with their hands) 


\subsection{Respect}

The concept of respect is often considered in a moral way rather than being accepted as an intrinsic motivation. When its importance is thought of especially from its moral angle; it draws the attention as a value that the children should have especially at young ages.

Human behaviours are categorised under three main groups such as inborn behaviours, temporary behaviours and acquired behaviours. (Kaya, 2012: 15) According to this approach, the concept of respect is under the acquired behaviours category and this concept needs to be made permanent and not being left temporary. Examples given about the concept of respect are given below:

"There is an old grandfather who lives alone in the apartment which Arda lives in. This grandfather has a son who visits him from time to time but these visits are getting rarer day by day.Arda observes this situation and one day he decides to surprise the grandfather with his friends. Arda and his friends tell their mothers to cook delicious dishes and take these dishes to the grandfather.The grandfather who is incapable of cooking his own food from an old age becomes very happy of the situation."

The musical play which aims gaining respect especially towards elderly people is given below:

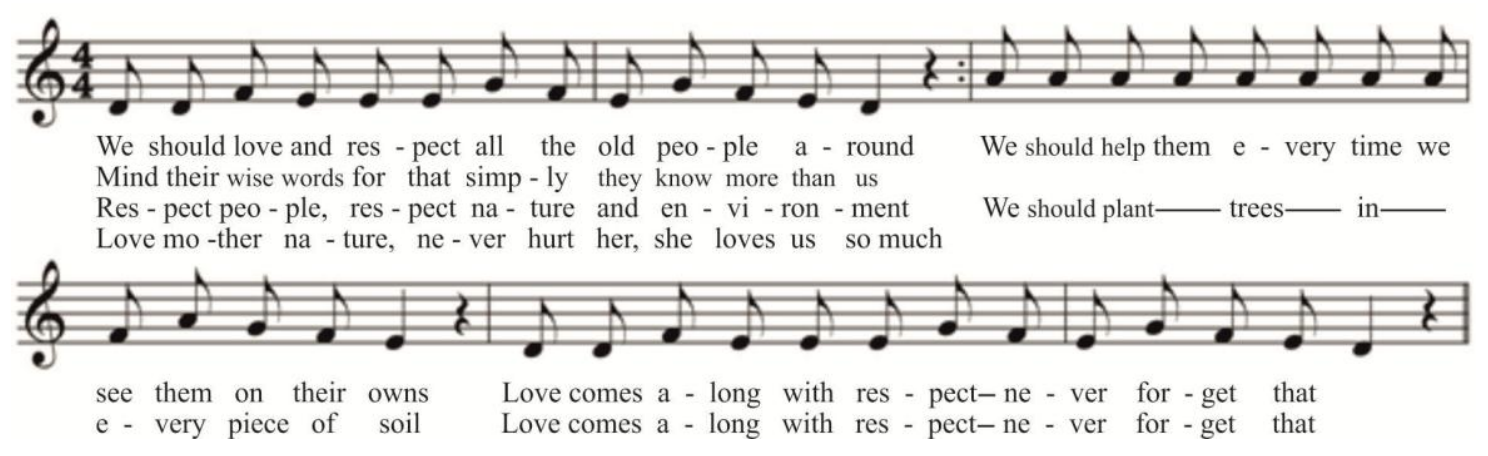

We should love and respect all the old people aroundMind their wise words for that simply they know more than usWe should help them every time we see them on their ownsLove comes along with respect, never forget thatRespect people, respect nature and environmentLove mother nature, never hurt her, she loves us so muchWe should plant trees in every piece of soilLove comes along with respect, never forget that

The movements of the play are given below:

A group of students dress up as old people, other students makes some moves to show their respect to older people.

In "Mind their wise words..." line, the students imitate the speaking action with their hands.

In "We should help them every time..." line, children's group makes some movements to show that they help the elderly-dressed group.

In "Love comes along with respect..." part, the groups hug each other.

In "Respect people, respect nature..." line some children pretends to be trees.

In "Love mother nature..." line, a student pretends to be a flower while another one pretends to be a butterfly.

In "We should plant trees..." line, all students pretend to plant trees.

In "Love comes along with respect..." part, the groups hug each other again.

\section{Conclusion}

It is known how greatly the schools take a part in preparing the children to life. One of the most important elements in social living that should be paid attention to are values. For children who are actually little individuals to become more compatible in society, values education can be benefit from. For these reasons, values education should be attached importance to in child education.

It is possible to benefit the music phenomenon in this respect. Because music, especially musical plays draw the attention of children in audial, effective and psychomotor ways. To focus on the studies in this field and to reveal original studies more often will make children show importance to not only music lessons but also their other classes as well as it will help them to achieve to knowledge and abilities in far easier ways, help them easily remember what they have learnt and implement them to their lives.

\section{Suggestions}

In addition toexpand of these studies; musical plays should also be arranged for values education.Especially the preservice teachers who study in Primary School Teaching Department should be encouraged to do researches in this field, their creative should be appreciated and the advantages they have in 
educational ways should be told them in wide perspectives. It should not be forgotten that an literate future will only be forged with the individuals who are well-educated, knowledgeable, respective and lenient to each other, can look the event in a wide perspective and those who know how they will achieve knowledge.

\section{Books:}

\section{References}

[1]. ALPÖGE, G.(2011):OkulÖncesindeDeğerEğitimi ,BilgiYayınevi,Ankara.

[2]. AYDIN, M.Z.,AKYOL GÜRLER, Ş.(2012): OkuldaDeğerlerEğitimiYöntemler-Etkinlikler-Kaynaklar,NobelYayınDağıtım, EğitimBilimleri Nu:70,Ankara.

[3]. BACANLI,H.,ÇELIKÖZZ,N.,ERISSEN,Y.,ŞAHIN,M.,EYYAM,R.,DOĞRUER,N.,MENEVIŞ,I.,ÖZERBAŞ,M.A.,ÖZÜ,Ö.,, ÇAKMAK,M.,KILIÇ,D.,GÜNDOĞDU,K.,KAYABAȘI,Y.,SILMAN,F.,BAYSEN,E.,ERIŞTİ,B.,AKDENIZ,C.,TOK,H.,SÜNBÜL, A.M.,KURNAZ,A.,KARATAŞ,E.,KARATAŞ,S.,YALIN,H.İ,Editör:KAYA,

Z.(2012):ÖğrenmeveÖğretmeKuramlar,Yaklaşımlarve Modeller, PegemAkademi,Ankara.

[4]. DİLMAC,,B.(2002):İnsancaDeğerlerEğitimi,NobelYayınDağıtım, Ankara.

[5]. REARDON, B.A.(2000):Hoşgörü: BarışaAçıllanKapı, UnescoYayını,TiHAKYayınları/3,ÖğretmeninKitaplı̆̆ı, 2.Baskı,Ankara.

Journal Papers:

[6]. $\quad$ ELBİR ,B., BAĞCI, C.,DeğerlerEğitimiÜzerineYapılmışLisansüstüDüzeyindekiÇalışmalarınDeğerlendirilmesi, Turkish Studies International Periodical For The Languages, Literature and History of Turkish or Turkic, Volume 8/1, Winter 2013, s: 1321-1333. http://www.turkishstudies.net/Makaleler/1923597175_65_ElbirBilal-Canba\%C4\%9Fc\%C4\%B1-edb.pdf (Date Accessed: 08.05.2015)

[7]. KIILU,K, The concept of preschool music education in Estonian education system, Procedia - Social and Behavioral Sciences 29, 2011,p: $1257-1266$

http://ac.els-cdn.com/S1877042811028229/1-s2.0-S1877042811028229-main.pdf? tid=9b051ab4-f663-11e4-b24300000aab0f26\&acdnat=1431187019_46bfc9a1db51f963285f436699b5174e (Date Accessed: 08.05.2015)

[8]. KOUVAVA, S., ANTONOPOULOU,K., ZIOGA,S., KARALI,C.,The influence of musical games and role-play activities upon primary school children's self-concept and peer relationships, Procedia - Social and Behavioral Sciences Volume 29,2011, p: 1660 1667

http://ac.els-cdn.com/S187704281102876X/1-s2.0-S187704281102876X-main.pdf?_tid=58f8aab4-f663-11e4-9535-

00000aacb35e\&acdnat=1431186908_0249a8d6bc382e35daf948d4717acfc3 (DateAccessed: 08.05.2015)

[9]. ÖZENSEL,E., SosyolojikBirOlguOlarakDeğer, DeğerlerĔgitimiDergisi, C.1, S.3.2003,s:217-239

https://www.academia.edu/9873315/Say\%C4\%B1_3_Cilt_1_Sosyolojik_Bir_Olgu_olarak_De\%C4\%9Fer_Uzm._Ertan_\%C3\%96z ensel (Date Accessed:08.05.2015)

[10]. YAZICI,K.,DeğerlerEğitimineGenelBirBakıș, TÜBAR-XIX-/2006-Bahar,2006, s: 499-522

http://www.tubar.com.tr/TUBAR\%20DOSYA/pdf/2006BAHAR/19.31.kubilayyazici.s.499-522.pdf (Date Accessed: 08.05.2015)

\section{Internet References}

[11]. http://tkb.meb.gov.tr/program2.aspx?islem=1\&kno=88 (Date Accessed: 08.05.2015) 